\title{
Determinants of Effective Monitoring and Evaluation System of Public Health Programs: A Case Study of School-Based Hand Washing Program in Kwale County, Kenya
}

\section{Lamech Otieno Okello, Fred Mugambi}

School of Human Resource and Development, Jomo Kenyatta Univeristy of Agriculture and Technology, Juja, Kenya

Email address:

lamechotieno@yahoo.co.in (Okello L. O.), fmgambi@gmail.com (Mgambi F.)

\section{To cite this article:}

Lamech Otieno Okello, Fred Mugambi. Determinants of Effective Monitoring and Evaluation System of Public Health Programs: A Case Study of School-Based Hand Washing Program in Kwale County, Kenya. International Journal of Economics, Finance and Management Sciences. Vol. 3, No. 3, 2015, pp. 235-251. doi: 10.11648/j.ijefm.20150303.20

\begin{abstract}
The main objective of the study was to identify determinants of effective monitoring and evaluation of public health programs, a case study of School based hand washing project in Kwale County which is implemented by Ministry of Health, Ministry of Education and other partners. Monitoring and evaluation is an essential and critical undertaking in any project or program. It assists the management to learn about their own activities and results, to support internal planning and development and accountability to their stakeholders. Organisations/programs need evidence of their efficiency and effectiveness for funders, commissioners and investors or generally all the stakeholders. Monitoring and evaluation is critical to public health programs locally and globally, as donors, governments, and other relevant stakeholders must validate their investments and improve program performance. Globally evaluation and repeated monitoring of a range of indicators reflecting hand hygiene infrastructures and practices is a vital component of any successful hand hygiene campaign. The data for the study was collected using descriptive research design where questionnaires were administered to team leaders, supervisors and other personnel who were involved in implementing the project to demonstrate associations or relationships between the variables. Statistical Package for Social Sciences (SPSS) version 16.0 was used to analyze the data, descriptive statistics was used for data presentation. The study concluded that project human resource plays a vital role in monitoring and evaluation of public health programs and the project team should be composed of specialized staffs that are properly trained to conduct monitoring and evaluation. According to the study, key informants were aware and knowledgeable of hand washing project in Kwale County. For monitoring and evaluation systems to be functional properly, advocacy strategies need to be developed and supported within the organization. Also a culture to support monitoring and evaluation should be developed within the organization. The study made some recommendations which included involvement of all the stakeholders in School based hand washing project as this will assist in strengthening monitoring and evaluation unit, advocacy strategies on School based hand washing project in Kwale County needed some improvement.
\end{abstract}

Keywords: Monitoring, Evaluation System, Public Health Programs, School-Based Hand Washing Program

\section{Introduction}

\subsection{Background of the Study}

Public Health can be broadly defined as what a society does collectively to assure the conditions in which people can be healthy (Amanda, 2010) .Public Health Program works to strengthen the capacity of marginalized populations to advocate for better health policies and practices. It also pushes for greater government accountability in health care. Public health activities focus on prevention, promotion and protection rather than on treatment, on populations rather than on individuals, and on the factors and behaviours that cause illness and injury rather than the illness and injury (Perlino, 2006). Throughout the world, people who face stigma and discrimination are often left with substandard or no health care. In Eastern Europe, ambulances routinely refuse to answer calls for help from Roma communities, in countries of the 
former Soviet bloc; people with mental disabilities are forced to live in remote and dilapidated institutions, without access to education or health care, in Asia, people who are addicted to drugs are locked away in "rehabilitation" centers where they are flogged, chained to their beds, and forced to perform unpaid labor-with no genuine treatment in sight, in many countries worldwide, people with AIDS or cancer are left to suffer in excruciating pain, without access to affordable, essential medicines such as oral morphine (Sanderson and Gruen, 2006).These factors promote the need for public health programs within the community.

Public Health Program includes the following projects and initiatives: Access to Essential Medicines Initiative; Accountability and Monitoring in Health Initiative; Global Health Financing Initiative; Health Medical Initiative; International Harm Reduction Development Program; International Palliative Care Initiative which involves end-of-life care for patients and their families, with a special focus on vulnerable populations including the elderly, children, and patients with cancer or AIDS; Law and Health Initiative; Mental Health Initiative; Sexual Health and Rights Project.

Hand washing for hand hygiene is the act of cleaning one's hands with or without the use of water or another liquid, or with the use of soap, for the purpose of removing soil, dirt, and/or microorganisms (UNICEF, 2008) .It protects best against diseases transmitted through faecal-oral routes (such as many forms of stomach flu) and direct physical contact (such as impetigo).Global Hand washing Day (GHD) is a campaign to motivate and mobilize millions around the world to wash their hands with soap. It takes place on October 15 of each year. The campaign is dedicated to raising awareness of hand washing with soap as a key approach to disease prevention. Illness causes many children around the world to miss significant amounts of schooling. Studies have shown, for instance, that worm infections (which may result from poor hygiene, such as not washing hands before eating) can cause irregular school attendance and may negatively affect children's cognition and performance when they are at school (Curtis and Cairncross,2003).

A number of infectious diseases can be spread from one person to another by contaminated hands, particularly gastrointestinal infections, influenza and hepatitis A. Washing your hands properly can help prevent the spread of the organisms that cause these diseases.

\subsection{Statement of the Problem}

At the World Education Forum in Dakar in 2000, international agencies agreed on a common framework for school health programs- FRESH (Focusing Resources on Effective School Health). FRESH supports efficient, realistic and results-oriented implementation of school health programs (hand washing) to make schools healthier for children to learn and where children learn to be healthy. These programs help ensure that children enrol and stay in schools, learn more while in school and develop skills, knowledge and healthy behaviours that protect themselves and their future children from disease. School health programs contribute to the Education for All (EFA) goals to improve the quality of education and learning outcomes, while also indirectly contributing to the major health and development goals by promoting healthy behaviours amongst school children and the broader community in which they live (UNESCO, 2000). Human faeces are the main source of diarrheal pathogens.

They are the source of shigellosis, typhoid, cholera, all other common endemic gastro-enteric infections and some respiratory infections such as influenza and pneumonia. A single gram of human faeces can contain 10 million viruses and one million bacteria. These pathogens are passed from an infected host to a new one via various routes but all of these illnesses emanate from faeces. Removing excreta and cleaning hands with soap after contact with faecal material -from using the toilet or cleaning a child - prevents the transmission of the bacteria, viruses and protozoa that cause diarrheal diseases (WHO, 2009). In the implementation of public health programs, monitoring and evaluation is something that is seen as a donor (funder) requirement rather than a management tool. Donors are certainly entitled to know whether their money is being properly spent, and whether it is being well spent. But the primary (most important) use of monitoring and evaluation should be for the organisation or project itself to see how it is doing against objectives, whether it is having an impact, whether it is working efficiently, and to learn how to do it better. Research shows that children living in households exposed to hand washing promotion and soap had half the diarrheal rates of children living in control neighbourhoods. The simple act of washing hands with soap can significantly cut the risk of diarrhoea from 30 percent to 50 percent and that of respiratory tract infection from 21 percent to 45 percent (Curtis and Cairncross, 2003).

UNICEF estimates that diarrhoea kills one child every 30 seconds. In 2005 Fewtrell et al. (2005) compared the effectiveness of hand washing with soap for reducing diarrheal illness to other interventions. Acute respiratory infections such as pneumonia are another primary cause of child deaths. A study in Pakistan found that hand washing with soap reduced the number of pneumonia-related infections in children under five by more than 50 percent, as well as skin infection - impetigo - by 34 percent. Research suggests that soap is available in most households in the world, including poor households in developing countries although it is primarily used for bathing and washing clothes. Diarrhoea is responsible for children missing hundreds of millions of school days every year. By having children integrate the habit of hand washing with soap in their daily routines, school absenteeism could be reduced substantially. A recent study suggests that hand washing with soap at critical times could help reduce school absenteeism by around 42 percent (Bowen, 2007)). Good hand washing technique is easy to learn and can significantly reduce the spread of infectious diseases in both children and adults (Utah Dept. of Health, 2000). Hand washing with warm water and soap can greatly reduce the chances of spreading or getting of these infectious diseases. Diarrhoea, cholera and respiratory infections are worldwide spread and rampant in tropical counties (World Bank, 2006). 
Kwale County is an example of such region. To successfully promote the practice of hand washing with soap in Schools, public and private sector partners are drawing on their comparative strengths, resources, and best practices to create effective, large scale, and sustainable hand washing promotion programs in Kwale to reduce absenteeism. Monitoring and evaluation are both tools which help a project or organisation implementing public health programs know when plans are not working, and when circumstances have changed. They give management the information it needs to make decisions about the project or organisation, about changes that are necessary in strategy or plans.

The lessons learned after conducting the study will assist the Ministries of Health, Education, stakeholders and community-based groups on effective and efficient way of managing public health programs. The integrity of monitoring and evaluation system must be upheld.

Important decisions are made based on the information and insights provided by the system.

Projects are terminated, and judgments made based on the reports and documents prepared by the monitor and the evaluator. When the integrity of the system is compromised, monitoring and evaluation will do more harm than good.

\subsection{The Objectives of the Study}

\subsubsection{General Objective}

The general objective of the study was to assess the determinants of effective monitoring and evaluation system of public health programs in Kwale County.

\subsubsection{Specific Objectives}

i. To analyse the effects of human resource on effective monitoring and evaluation system of public health programs in Kwale County.

ii. To determine the effects of organizational culture on effective monitoring and evaluation system of public health programs in Kwale County.

iii. To evaluate the effects of stakeholders on effective monitoring and evaluation system of public health programs in Kwale County.

iv. To assess whether advocacy influences effective monitoring and evaluation system of public health programs in Kwale County.

\subsection{Research Questions}

The research questions which the study intended to answer include;

i. How does human resource influence effective monitoring and evaluation system of public health programs in Kwale County?

ii. How does organizational culture influence effective monitoring and evaluation system of public health programs in Kwale County?

iii. How do stakeholders influence effective monitoring and evaluation system of public health programs in Kwale County?

iv. How does advocacy influence effective monitoring and evaluation system of public health programs in Kwale County?

\section{Literature Review}

\subsection{Social Science Theory}

Social science theories are especially concerned with the attempt to provide generalizable and verifiable knowledge about the principles that shape social behavior. When such theories address the social phenomena related to social programs and the social conditions they are intended to improve, however, they may be very relevant to evaluation (Alkin, 2004). In this study, Social science theory can play several important roles in evaluation practice. First, such theory and prior research can be very informative for initial needs assessment and program design. Many, if not most, social problems have been encountered by others, and sometimes research or evaluation on efforts to prevent or solve these problems exist. A careful examination of available literature, including primary studies as well as syntheses such as meta analyses, may turn up knowledge about effective strategies for dealing with the problems of concern, or just as important (and probably more likely), lessons learned about what does not work, which may save program designers and evaluators countless hours and resources (Donaldson, 2001).

Social science theory and research are useful in this study for guiding evaluation measurement and design decisions, and can provide a context for interpreting evaluation findings. For example, it is sometimes possible to locate relevant and valid measures of constructs of interest or feasible designs that have lead to unequivocal findings, as well as measures and designs that are not likely to lead to valid results in your work. Previous theory and research can also provide a context, or suggest expectations for the range of effect sizes evaluators should expect. Estimated effect sizes in the current evaluation can be compared to previous findings in an effort to further explore the relative practical significance of the program under investigation (Donaldson et al. 2001; Lipsey, 1990). The notable boundary conditions that must be acknowledged when using social science theory and research in evaluation practice is the limit of generalizability. The characteristics of previous research and evaluation are to various degrees different than those in the current investigation. Some evaluation theorists have suggested that evaluators should be much more concerned about producing local knowledge than concerning themselves with producing generalizable knowledge (Alkin and Christie, 2004).

Evidenced based social science theories are often helpful for understanding the etiology of desired or undesired outcomes and for developing intervention strategies for influencing those outcomes. For example, social learning theory has been used effectively to design programs to promote positive social norms to prevent alcohol and drug use, risky sexual behavior, breast cancer, and range of other social and behavioral problems (Bandura, in press; Donaldson, Graham, \& Hansen, 1994; Petraitis, Flay, \& Miller, 1995). 
Many such social science theories have been, or might be, used for designing, improving, and evaluating programs: Prochaska and DiClemente's (1999) theory of health behavior change, Kram's (1997) theory of mentoring.

\subsection{Program Theory}

Program theory is much more modest and deals with the assumptions that guide the way specific programs, treatments, or interventions are implemented and expected to bring about change (Donaldson, 2001; Lipsey, 1993).Program theory is concerned with how to practice evaluation, program theory focuses on the nature of the program, treatment, intervention, policy, etc. being evaluated. In evaluation practice today, Program theory is define as follows: The construction of a plausible and sensible model of how a program is supposed to work (Bickman, 1987); A set of propositions regarding what goes on in the black box during the transformation of input to output, that is, how a bad situation is transformed into a better one through treatment inputs (Lipsey, 1993); The process through which program components are presumed to affect outcomes and the conditions under which these processes are believe to operate (Donaldson, 2001).

Rossi, Lipsey, and Freeman (2004) described program theory as consisting of three main components, as follows; The organizational plan -How to garner, configure, and deploy resources, and organize program activities so that the intended service delivery system is developed and maintained; The service utilization plan-How the intended target population receives the intended amount of the intended intervention through interaction with the program's service delivery system. The impact theory, how the intended intervention for the specified target population brings about the desired social benefits. The organizational and service utilization plans together constitute the program process theory and the impact component is referred to as program impact theory. This form of practical program theory is often referred to as the "program logic" and various logic modeling techniques and ways of depicting program logic have become commonplace in evaluation practice (Funnel, 1997; Gargani, 2003).Program process theory must usually be developed from information that comes almost entirely from the program and its immediate context.

At the most practical level, a well-developed and fully articulated program theory is useful for this study for framing key evaluation questions and designing sensitive and responsive evaluations. By indicating clearly what is assumed and expected in the operation and outcomes of a program, program theory helps the evaluator and program stakeholders identify the performance dimensions most critical to the program's success and, hence, those that may be most important to assess. The theoretical framework will strengthens the study in the following ways; an explicit statement of theoretical assumptions permits the reader to evaluate them critically; the theoretical framework connects the researcher to existing knowledge; guided by a relevant theory, you are given a basis for your hypotheses and choice of research methods; articulating the theoretical assumptions of a research study forces you to address questions of why and how.

It permits you to move from simply describing a phenomenon observed to generalizing about various aspects of that phenomenon; having a theory helps you to identify the limits to those generalizations. A theoretical framework specifies which key variables influence a phenomenon of interest. It alerts you to examine how those key variables might differ and under what circumstances.

\subsection{Conceptual Framework}

The figure below shows the relationship between the variables i.e. Independent variable and dependent variable. Independent variable is what is varied during the experiment; it is what the investigator thinks will affect the dependent variable. Mugenda (1999), an independent variable influences and determines the effect of another variable. Independent variables in this study are Human resource availability, organization culture, Stakeholders and advocacy. Dependent variable is what will be measured; it's what the investigator thinks will be affected during the experiment (Zechmeister, Zechmeister, and Shaughnessy, 2001).

Dependent variable in this study is effective monitoring and evaluation of public health projects.

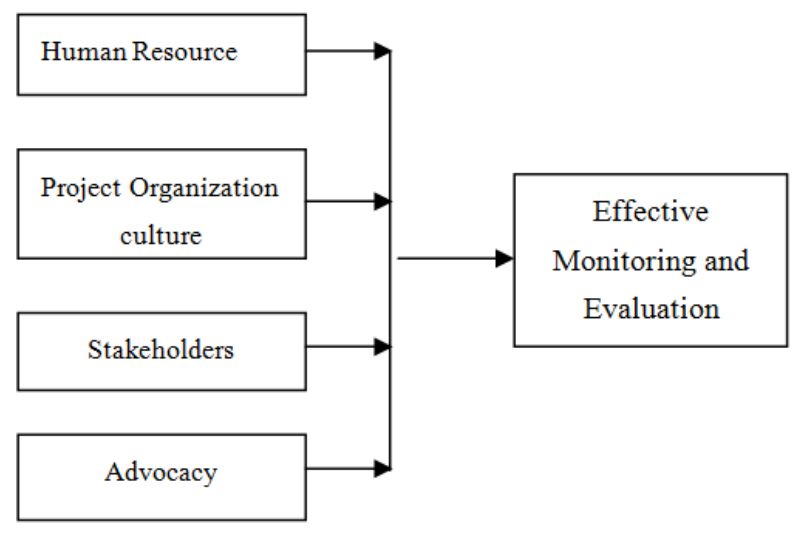

Independent variables

Dependent variable

Figure 1. A conceptual framework of determinants of Effective Monitoring and evaluation of public health programs.

\subsection{Human resource for Monitoring and Evaluation of the Program}

Inadequate human resource leads to poor quality monitoring and evaluation. To ensure effective and quality monitoring and evaluation, it is critical to set aside adequate human resource at the planning stage. Human capacity building is vital for quality monitoring and evaluation, it is any support that strengthens an organization's ability to effectively and efficiently designs implement and evaluate program activities according to its mission (UNICEF Namibia, 2008).

The technical capacity of the organization in conducting monitoring and evaluation, the value and participation of its human resources in the policymaking process, and their 
motivation to impact decisions, can be huge determinants of how the evaluation's lessons are produced, communicated and perceived (Vanessa and Gala, 2011).Human resource is critical for effective monitoring and evaluation, even after securing adequate financial resources. For high-quality monitoring and evaluation, there should be: dedicated staff time - for effective monitoring and evaluation; staff should be dedicated for the function.

The practices of deployment of personnel for monitoring vary among organizations. Organizations should establish monitoring and evaluation units with specific terms of references (ToRs), dedicated skilled staff, work plans and other resources; skilled personnel-Staff entrusted with monitoring should have required technical expertise in the area. Where necessary, skill levels should be augmented to meet the needs and with ongoing investments in developing such capacity within the organization as necessary. Human resources on the project should be given clear job allocation and designation befitting their expertise, if they are inadequate then training for the requisite skills should be arranged. For public health projects with staff that are sent out in the field to carry out project activities on their own there is need for constant and intensive on-site support to the outfield staff (Collings and Wood, 2009).

Human capacity building should focus on all levels of the system. M\&E capacity building should focus not only on the technical aspects of M\&E, but also address skills in project management, leadership, financial management, facilitation, supervision, advocacy and communication. The largest aspects of developing employee's skills and abilities are the actual organizational focus on the employee to become better, either as a person or as a contributor to the organization. The attention by the organization coupled with increased expectations following the opportunity can lead to a self-fulfilling prophecy of enhanced output by the employee (Pearce and Robinson, 2005).Monitoring and evaluation must also be independent and relevant. Independence is achieved when it is carried out by entities and persons free of the control of those responsible for the design and implementation of the development intervention.

\subsection{Organization Culture and Monitoring and Evaluation}

There are numberless definitions about organizational culture, which is defined in many different ways in the literature. The most commonly known definition is "the way we do things around here" (Lundy \& Cowling, 1996). According to Marshal (2002), cultural elements include norms, values, behaviour patterns, rituals and traditions within an organization. Culture includes the organization's vision, values, norms, systems, symbols, language, assumptions, beliefs, and habits. It is also the pattern of such collective behaviours and assumptions that are taught to new organizational members as a way of perceiving, and even thinking and feeling (Burman and Evans, 2008). Another opinion regards organization culture as a system of shared values (what is important) and beliefs (how things work) that interact with a company's people, organization structures, and control systems to produce behavioural norms (Uttal, 1983). Culture within an organization is playing a critical role in the organization's everyday operations. Organizational culture is manifested in the typical characteristics of the organization and should be regarded as the right way in which things are done or problems should be understood in the organization.

Ravasi and Schultz (2006) stated that organizational culture is a set of shared mental assumptions that guide interpretation and action in organizations by defining appropriate behaviour for various situations. It provides a "set theory" of important values, beliefs, and understandings that members share in common, better (or the best) ways of thinking, feeling and reacting that could help managers to make decision and arrange activities of organization. A successful organization should have strong cultures that can attract, hold, and reward people for performing roles and achieving goals, whereas strong cultures are usually characterized by dedication and co-operation in the service of common value. Culture is a learned entity; at a basic level, culture may be defined as "the way we do things around here" or "the way we think about things around here" (Williams et al, 1994).Managers should predict or grasp the general trend of employees' behaviours and thinking and this will be useful as the correct way for new employees to behave, thereby, culture can perpetuate organizational survival and growth; culture is viewed as a belief system. Davis (1984) defines culture as: "The pattern of shared beliefs and values that give members of an institution meaning, and provide them with the rules for behaviour in their organization.

Organizational culture can be divided into fundamental guiding beliefs and daily beliefs and advocates that guiding beliefs provide the context for the practical beliefs of everyday life, that is to say, guiding beliefs give direction to daily beliefs. As fundamental precepts, guiding beliefs rarely change since they are in the realm of universal truth (Adkins and Caldwell, 2004). On the other hand, daily beliefs are also part of the company culture and can be described as the rules and feelings about everyday behaviour. However these are dynamic and situational; they have to change to match context. Organization culture can be seen as strategy. Bate (1995) defines "culture is a strategic phenomenon: strategy is a culture phenomenon." That is to say, there are twofold implications of such beliefs: first, any kind of strategy formulation is a cultural activity, for example, the development of strategy is just a cultural development; second, all cultural changes should be viewed as strategic changes.

Culture is the "collective programming of the mind, which distinguishes the members of one category of people from another." divided culture can be divided into four layers (or four main elements): symbols, heroes, rituals and values. The four layers are critical for organizational managers, because it can affect operations of the organization at different degree and in different ways. Organizational culture is playing an indirect role in influencing behaviour by using reasonable managerial tools, such as strategic direction, goals, tasks, technology, structure, communication, decision making, cooperation and interpersonal relationships, and so forth, 
which are all designed to do things (Martins \& Terblanche, 2003). Every organization has its own unique culture or value set, and different organization may have its own comprehension of culture meaning. The culture of the organization is typically created unconsciously, based on the values of the top management or the founders of an organization. Organisational culture is one of the most influential dimensions of the work climate and consecutively the main driving force within an organization.

Culture affects decision-making, thinking, feeling and the response to opportunities and threats. It also affects how people are chosen for a particular task, which affects performances and decision making. Culture is rooted in people and subconsciously influences their behaviour, it affects their performance and vice versa. Such culture can be described as follows: "That's the way we do it!" (Alvesson, 2002 ) or "The way things are done around here" (Lewis, 1995).Organisational culture has a number of underlying factors - it is formed by a set of values, beliefs, assumptions, common understandings, expectations, attitudes, behaviours, thinking, norms and traditions of the people in an organization (Davidson, 2000), and is also affected by ethnic cultures (Lewis, 1995).

Culture also represents a person's attitudes arising out of their professional, religious, class, educational, gender, age and other backgrounds and people's capacity for learning and transmitting knowledge (Turner \& Simister, 2000). It can be described by three levels: artefacts, espoused values, and basic, underlying assumptions (Eskerod \& Skriver, 2007). All of the mentioned dimensions of culture are shared by all members of an organization and guide how employees get work done. The organisational context of a culture serves as a foundation for the methods of operation, an organisation's management system as well as a set of management practices and behaviours that both exemplify and reinforce those basic principles (Davidson, 2000). Organizations needs to develop a culture such as working together at different levels and systems coordinated centrally to promotes and encourages monitoring and evaluation. Both financial and material resources should be in place for effective monitoring and evaluation.

\subsection{Stakeholder Participation and Monitoring Evaluation}

A primary feature of Monitoring and Evaluation plan is the identification of stakeholders, which includes members who have a stake or vested interest in the evaluation findings, those who are the intended users who can most directly benefit from the evaluation (Patton, 2008; Knowlton, Philips, 2009), as well as others who have a direct or indirect interest in program implementation. Engaging stakeholders enhances intended users' understanding and acceptance of the utility of evaluation information. Stakeholders are much more likely to buy into and support the evaluation if they are involved in the evaluation process from the beginning. To ensure that the information collected, analyzed, and reported successfully meets the needs of the program and stakeholders, it is best to work with the people who will be using this information throughout the entire process. Engaging stakeholders in discussions about the what, how, and why, of program activities is often empowering for them and additionally, promotes inclusions and facilities meaningful participation by diverse stakeholder groups (Donaldson, 2003).

Stakeholders are consumers of the evaluation results. As consumers, they will have a vested interest in the results of the evaluation. Generally, stakeholders are those who are: interested in the program and would use evaluation results, such as clients, community groups, and elected officials; those who are involved in running the program, such as program staff, partners, management, the funding source, and coalition members; and those who are served by the program, their families, or the general public. Stakeholder participation means empowering development beneficiaries in terms of resources and needs identification, planning on the use of resources and the actual implementation of development initiatives (Chitere, 1994).

It is often said of public health programs, "everyone is your stakeholder." Stakeholders will often have diverse and, at times, competing interests. Given that a single evaluation cannot answer all possible evaluation questions raised by diverse groups it will be critical that the prioritization process is outlined in the evaluation plan and that the stakeholder groups represented are identified. Best practice example demonstrates that a central factor facilitating to self-reliance in overall programme implementation; update of evaluations is stakeholder involvement. This involvement must be brought in at the early stages of the Evaluation process, include the support of high profile champions and attract political agents interested in learning or using instruments to demonstrates effectiveness (Jones,2007). Engaging stakeholders in an evaluation can have many benefits. In general, stakeholders include people who will use the evaluation results, support or maintain the program, or who are affected by the program activities or evaluation results. Stakeholders can help-determine and prioritize key evaluation questions, pre-test data collection instruments, facilitate data collection, implement evaluation activities, increase credibility of analysis and interpretation of evaluation information, and ensure evaluation results are used.

Bamberger (2009) also found that the whole process of impact evaluation and particularly the analysis and interpretation of results can be greatly improved by the participation of intended beneficiaries, who are after all the primary stakeholders in their own development and the best judges of their own situation. However, stakeholders engagement needs to be managed with care too much stakeholder's involvement could lead to undue influence on the evaluation, and too little could lead to evaluators dominating the process (Patton, 2008).Benefits of Stakeholder Participation in M\&E Planning and Implementation in public health programs includes: Ensures that the M\&E findings are relevant to local conditions; Gives stakeholders a sense of ownership over M\&E results thus promoting their use to improve decision-making; Increases the understanding of stakeholders of their own program strategy and processes; 
what works, does not work and why; Contributes to improved communication and collaboration between programme actors who are working at different levels of programme implementation; Strengthens accountability to donors; Promotes a more efficient allocation of resources (Aubel, 1999. UNDP, 1997).

However, exactly what program stakeholders are involved in $M \& E$ varies according to the purpose of $M \& E$ and the general institutional receptiveness to the use of participatory approaches. In each instance, program managers must decide which group of stakeholders should be involved, to what extent and how. To be effective, monitoring and evaluation should be both participatory and strategic. M\&E is participatory when it includes all stakeholders in the process and is strategic when it deals with fundamental issues. Successful outcome will normally depend on forging consensus among a diverse set of stakeholders. Participation can be in many forms but always validate and mobilizes support for the process.

\subsection{Advocacy in Monitoring and Evaluation}

Advocacy is defined as any action that speaks in favour of, recommends, argues for a cause, supports or defends, or pleads on behalf of others. Advocacy is the active support of an idea or cause expressed through strategies and methods that influence the opinions and decisions of people and organizations when conducting Monitoring and Evaluation. In the social and economic development context the aims of advocacy are to create or change policies, laws, regulations, distribution of resources or other decisions that affect people's lives and to ensure that such decisions lead to implementation and success in Monitoring and Evaluation systems (Sprechman and Pelton, 2001). Advocacy strategies involve members of staff, their partner organisations and members of the community in working towards changes in legislation, policy and/or the law within the organization to support monitoring and evaluation.

Advocacy work is carried out through activities such as lobbying, campaigning, awareness raising, direct actions and working with the media (Gosling and Cohen, 2007). An essential central element of any advocacy strategy in monitoring and evaluation is building the capacity of key stakeholders. Stakeholders include everyone who will use the information generated from the M\&E plan. This may include several levels of stakeholders from the international (e.g., donors) and national levels (e.g., Cabinet secretaries) to sub-national (e.g., County, Sub County) and program levels (e.g., program managers and service providers). Monitoring and evaluation advocacy can be conducted at different levels: International levels, including international conventions and treaties, and donor development policies; Regional levels, including regional institutions' policies and strategies, and national policies which are common to a geographical region; National levels, including national legislation and government policies, resource allocation, and institutional structures; Local levels, including local implementation of legislation, debate on the distribution of resources, access to services, local policies and strategies.

Advocacy in monitoring and evaluation of public health programs involves educating and creating awareness among leaders within the organization and the general public of issues facing the community and the importance of aligning public policy to address the need. It does not endorse or oppose specific legislation, but rather informs the community at large how public policy decisions impact service provision (Novick, Morrow \& Mays, 2007). Approaches to advocacy within the organizations include; heightened awareness, contribution to debate, changed policies, Policy changes implemented, Positive changes to people's lives , they work to achieve changes in identified, Policy outcomes, Civil society outcomes,

\section{Research Methodology}

\subsection{Research Design}

According to Kothari (2004) research design is defined as framework that shows how problems under investigation will be solved. This study was conducted using descriptive research design to demonstrate associations or relationships between the variables. Descriptive studies are usually the best methods for collecting information that demonstrates relationships and describe the world as it exists. The descriptive survey was to ascertain how human resource, Project organization culture, stakeholders and advocacy influences effective monitoring and evaluation of Public health projects.

Bickman and Rog (1998) suggest that descriptive studies can answer questions such as "what is" or "what was." or "why" or "how "or "when. "Both quantitative and qualitative data can be collected using the design. Descriptive research designs are concerned with describing the characteristics of a particular individual or of a group and ascertain whether variables are associated (Kothari, 2004). Descriptive research involves gathering data that describe events and then organizes, tabulates, depicts, and describes the data collection (Glass \& Hopkins, 1984). It often uses visual aids such as graphs and charts to aid the reader in understanding the data distribution. Because the human mind cannot extract the full import of a large mass of raw data, descriptive statistics are very important in reducing the data to manageable form. The design was also chosen to reduce biasness.

\subsection{Population of the Study}

Polit and Hungler (1999) refer to the population as an aggregate or totality of all the objects, subjects or members that conform to a set of specifications. A research population is generally a large collection of individuals or objects that is the main focus of a scientific query. A population can also be defined as the complete set of subject that can be studied: people objects, animals, plants, organizations from which a sample may be obtained (Shao, 1999).

The target population for a survey is the entire set of units for which the survey data are to be used to make inferences. 
Thus, the target population defines those units for which the findings of the survey are meant to generalize. For the study the target population was all the project committee members responsible with Monitoring and evaluation of School based hand washing project (i.e. the public health officers and primary School health committee members) in the county where the sample was obtained. The total target population for the study was 578 people (38 PHO's and 540 school health committee members).

\subsection{Sampling Procedure and Sampling Size}

The sampling frame for the study was the population of the public health officers and school health committee members in the four Sub Counties in Kwale County (Kinango, Msambweni, Lungalunga and Matuga) .The list was obtained from the four Sub counties public health offices. According to Guilford and Frucher (1973), the sample size was calculated as follows:

$$
\mathrm{n}=\mathrm{N} /\left(1+\mathrm{N}(\mathrm{e})^{2}\right)
$$

$n=$ was the desired sample size when population is $<10,000$ $\mathrm{e}=$ Sampling error

$\mathrm{N}=$ Size of the population

In the study $95 \%$ confidence interval was applied and sampling error was 0.05

Therefore the sample size for this study was:

$\mathrm{n}=578 /\left(1+578(0.05)^{2}\right)=269.5$

$\mathrm{n}=270$

Sample size of each category (i.e. Project Managers and Sub-county School health committee members): $\%$ used $=$ $270 / 578=47 \%$

Table 3.1. Calculated sample size of Project Managers and Sub-counties School health committee members.

\begin{tabular}{lll}
\hline Project Managers & $47 \%$ of 38 & 17 \\
Sub- counties health County members & $47 \%$ of 540 & 253 \\
TOTAL & & 270 \\
\hline
\end{tabular}

The sampling technique used was purposive for the Project Managers and simple random sampling for Sub-counties School health committee members.

\subsection{Data Collection Procedure and Instruments}

Data collection instrument refers to the device used to collect data. Interview schedules and questionnaires was used administer questions for the study. A questionnaire is a research instrument consisting of a series of questions and other prompts for the purpose of gathering information from respondents. Questionnaires have advantages over some other types of surveys in that they are cheap, do not require as much effort from the questioner as verbal or telephone surveys, and often have standardized answers that make it simple to compile data (Gillham,2008). Questionnaire is the most commonly used method of gathering information because it is less costly way to reach more people, including people at some distance. Depending upon the method of distribution, it can be swiftly done and data analysis can begin right away. The questionnaire keeps away from interviewer bias, guiding and cues that can impact the legitimacy and reliability of the data collection. It will be used to collect quantitative data for the study. According to Kothari (2004) structured questionnaires best suited for descriptive study as it is easily applied and requires less skill. An interview is a one-on-one directed conversation with an individual using a series of questions designed to elicit extended responses. Because this method allows you to probe for greater depth or explanation, simple yes/no questions or fixed-response questions are typically not used. Mugenda and Mugenda (1999) said that a guided interview can be used to interview the respondents. Some may not understand the questionnaire because of the low level of education. Interviews allow participants to express their thoughts using their own words and organization and thus are particularly valuable for gaining insight.

Three fundamental types of research interviews are as follows: structured, semi structured and unstructured (Stewart and Shamdasani, 1990). Structured interviews are, essentially, verbally administered questionnaires; in which lists of predetermine questions are asked, with little or no variation and with no scope for follow-up questions to responses that warrant further elaboration. Consequently, they relatively quick and easy to administer and may be of particular use if clarification of certain questions are required or if there are likely to be literacy or numeracy problems with the respondents. However, by their very nature, they only allow for limited participant responses and are, therefore, of little use if 'depth' is required.

Conversely, unstructured interviews do not reflect any preconceived theories or ideas and are performed with little or no organization. Such an interview may simply start with an opening question such as 'Can you tell me about your experience of visiting the dentist?' and will then progress based, primarily, upon the initial response. Unstructured interviews are usually very time-consuming (often lasting several hours) and can be difficult to manage, and to participate in, as the lack of predetermined interview questions provides little guidance on what to talk about (which many participants find confusing and unhelpful). Their use is, therefore, generally only considered where significant 'depth' is required, or where virtually nothing is known about the subject area (or a different perspective of a known subject area is required).

Semi-structured interviews consist of several key questions that help define the areas to be explored, but also allows the interviewer or interviewee to diverge in order to pursue an idea or response in more detail (Kvale, 1996). This interview format is used most frequently in healthcare, as it provides participants with some guidance on what to talk about, which many find helpful. The flexibility of this approach, particularly compared to structured interviews, also allows for the discovery or elaboration of information that is important to participants but may not have previously been thought of as pertinent by the research team (May, 1991). Semi structure interviews were used to collect qualitative data in the study. The self-administered questionnaires were sent to the health committee members' secretary who distributed to the 
respondents and were picked later. The informant interview schedules were delivered personally by the researcher and research assistants for data collection.

\subsection{Data Processing Analysis and Presentation}

Data analysis refers to examining the collected data and making discussions, inferences and conclusions; Kothari (2004).The data collected were cleaned through data inspection and corrected for any errors identified. After that, data was processed (edited, classified and coded) and entered into the computer for analysis. Statistical Package for Social Sciences (SPSS) version 16 was used for processing and analysis of the data collected. Data was presented using descriptive statistics which involved the use of visual aids-tables and charts to aid the reader in understanding the data distribution. Because the human mind cannot extract the full import of a large mass of raw data, descriptive statistics are very important in reducing the data to manageable form. It provides simple summaries about the sample and the measures. Together with simple graphics analysis, they form the basis of virtually every quantitative analysis of data. The technique that was used was tabular description in which tables of numbers summarize the data. Descriptive statistics will provide graphical summaries that show the spread of the data, and numerical summaries that either measures the central tendency (a 'typical' data value) of a data set or that describe the spread of the data.

\section{Results and Discussion}

\subsection{Project Human Resource}

Project human resource is one of the factors which influences if a project is to be monitored and evaluated or not. The tables below shows the frequencies and percentages of the respondents as per the statement on project human resource and monitoring and evaluation of School based hand washing project in Kwale County.

Kwale County School based hand washing project has adequate specialized staffs to conduct monitoring and evaluation

Table 4.1. Adequate specialized staffs and monitoring and evaluation.

\begin{tabular}{lllll}
\hline Reaction & Frequency & Percent & $\begin{array}{l}\text { Valid } \\
\text { Percent }\end{array}$ & $\begin{array}{l}\text { Cumulative } \\
\text { Percent }\end{array}$ \\
\hline $\begin{array}{l}\text { Strong Agree } \\
\text { Agree }\end{array}$ & 36 & 17.5 & 17.5 & 17.5 \\
$\begin{array}{l}\text { Somehow } \\
\text { agree }\end{array}$ & 36 & 22.3 & 22.3 & 39.8 \\
$\begin{array}{l}\text { somehow } \\
\text { disagree }\end{array}$ & 11 & 18.4 & 18.4 & 58.3 \\
$\begin{array}{l}\text { Disagree } \\
\text { strongly }\end{array}$ & 51 & 5.3 & 5.3 & 63.6 \\
disagree & 24 & 24.8 & 24.8 & 88.3 \\
Total & 206 & 11.7 & 11.7 & 100 \\
\hline
\end{tabular}

From the table 4.1 above, the results reveal that $17.5 \%$ of respondent strongly agreed, $22.3 \%$ agreed, $18.4 \%$ somehow agreed, 5.3\% somehow disagreed, $24.8 \%$ disagreed and $11.7 \%$ strongly disagreed that, adequate specialized staffs are involved in monitoring and evaluation of School based hand washing project in Kwale County. The total percentage of the respondents who agreed is $58.3 \%$ while those respondents who disagreed is $41.7 \%$ which brings a cumulative percentage of $100.0 \%$.It can be deduced from the statistics that more than a half of the respondents agree that adequate specialized staffs play a major role in monitoring and evaluation of School based hand washing project in Kwale County.

You have received training on school based hand washing project in Kwale County. The response was as shown in table 4.2 .

Table 4.2. Training on School based hand washing project.

\begin{tabular}{lllll}
\hline Reaction & Frequency & Percent & $\begin{array}{l}\text { Valid } \\
\text { Percent }\end{array}$ & $\begin{array}{l}\text { Cumulative } \\
\text { Percent }\end{array}$ \\
\hline $\begin{array}{l}\text { Strong } \\
\begin{array}{l}\text { Agree } \\
\text { Agree }\end{array}\end{array}$ & 54 & 26.2 & 26.2 & 26.2 \\
$\begin{array}{l}\text { Somehow } \\
\text { agree }\end{array}$ & 19 & 18 & 18 & 44.2 \\
$\begin{array}{l}\text { somehow } \\
\text { disagree }\end{array}$ & 8 & 9.2 & 9.2 & 53.4 \\
$\begin{array}{l}\text { Disagree } \\
\text { strongly } \\
\text { disagree }\end{array}$ & 35 & 3.9 & 3.9 & 57.3 \\
Total & 53 & 17 & 17 & 74.3 \\
\hline
\end{tabular}

From table 4.2 above, $26.2 \%$ of respondents strongly agreed, $18.0 \%$ agreed, $9.2 \%$ somehow agreed, $3.9 \%$ somehow disagreed, $17.0 \%$ disagreed and $25.7 \%$ strongly disagreed that they are trained in monitoring and evaluation of School based hand washing project in Kwale County. The total percentage of the respondents who agreed is $53.4 \%$ while those respondents who disagreed is $41.7 \%$ which brings a cumulative percentage of $100.0 \%$. Statistics shows that more than a half of the respondents agree that they are trained in School based hand washing project in Kwale County which play a vital role in the monitoring and evaluation of the project.

The training I received includes M\&E, project management, advocacy and supervision of School based hand washing project. The response was as shown in table 4.3

Table 4.3. Training received includes $M \& E$, project management, advocacy and supervision.

\begin{tabular}{lllll}
\hline Reaction & Frequency & Percent & $\begin{array}{l}\text { Valid } \\
\text { Percent }\end{array}$ & $\begin{array}{l}\text { Cumulative } \\
\text { Percent }\end{array}$ \\
\hline $\begin{array}{l}\text { Strong } \\
\text { Agree }\end{array}$ & 23 & 11.2 & 11.2 & 11.2 \\
$\begin{array}{l}\text { Agree } \\
\text { Somehow }\end{array}$ & 45 & 21.8 & 21.8 & 33 \\
$\begin{array}{l}\text { agree } \\
\text { somehow } \\
\text { disagree }\end{array}$ & 13 & 15.5 & 15.5 & 48.5 \\
$\begin{array}{l}\text { Disagree } \\
\text { strongly }\end{array}$ & 23 & 6.3 & 6.3 & 54.9 \\
$\begin{array}{l}\text { disagree } \\
\text { Total }\end{array}$ & 70 & 11.2 & 11.2 & 66 \\
\hline
\end{tabular}


From table 4.3 above, $11.2 \%$ of respondents strongly agreed, $21.8 \%$ agreed, $15.5 \%$ somehow agreed, $6.3 \%$ somehow disagreed, $11.2 \%$ disagreed and $34 \%$ strongly disagreed that the training they received includes M\&E, project management, advocacy of School based hand washing project in Kwale County. The total percentage of the respondents who agreed is $48.5 \%$ while those respondents who disagreed is $51.5 \%$ which brings a cumulative percentage of $100.0 \%$. The data reveals that less than a half of the respondents agree that they are trained in M\&E, project management, advocacy of School based hand washing project in Kwale County.

Orientation on monitoring and evaluation of school based hand washing project is conducted regularly, the responses were as shown in table 4.4

Table 4.4. Orientation on $M \& E$ of school based hand washing project.

\begin{tabular}{lllll}
\hline Reaction & Frequency & Percent & $\begin{array}{l}\text { Valid } \\
\text { Percent }\end{array}$ & $\begin{array}{l}\text { Cumulative } \\
\text { Percent }\end{array}$ \\
\hline $\begin{array}{l}\text { Strong } \\
\text { Agree }\end{array}$ & 19 & 9.2 & 9.2 & 9.2 \\
$\begin{array}{l}\text { Agree } \\
\text { Somehow }\end{array}$ & 27 & 13.1 & 13.1 & 22.3 \\
$\begin{array}{l}\text { agree } \\
\text { somehow }\end{array}$ & 41 & 19.9 & 19.9 & 42.2 \\
disagree & 14 & 6.8 & 6.8 & 49 \\
$\begin{array}{l}\text { Disagree } \\
\text { strongly } \\
\text { disagree }\end{array}$ & 53 & 25.7 & 25.7 & 74.8 \\
Total & 52 & 25.2 & 25.2 & 100 \\
\hline
\end{tabular}

From table 4.4 above, $9.2 \%$ of respondents strongly agreed, $13.1 \%$ agreed, $19.9 \%$ somehow agreed, $6.8 \%$ somehow disagreed, $25.7 \%$ disagreed and $25.2 \%$ strongly disagreed that orientation on monitoring and evaluation of School based hand washing project in Kwale County is conducted regularly. The total percentage of the respondents who agreed is $42.2 \%$ while those respondents who disagreed is $57.8 \%$ which brings a cumulative percentage of $100.0 \%$. The data reveals that more than a half of the respondents disagree that orientation is done regularly which has a role to play on monitoring and evaluation of the project.

You have been orientated on M\&E data collection tool for School based hand washing project. They responded as shown in table 4.5

Table 4.5. Orientation on $M \& E$ data collection tool.

\begin{tabular}{lllll}
\hline Reaction & Frequency & Percent & $\begin{array}{l}\text { Valid } \\
\text { Percent }\end{array}$ & $\begin{array}{l}\text { Cumulative } \\
\text { Percent }\end{array}$ \\
\hline $\begin{array}{l}\text { Strong } \\
\text { Agree }\end{array}$ & 36 & 17.5 & 17.5 & 17.5 \\
$\begin{array}{l}\text { Agree } \\
\text { Somehow }\end{array}$ & 41 & 19.9 & 19.9 & 37.4 \\
$\begin{array}{l}\text { agree } \\
\text { somehow } \\
\text { disagree }\end{array}$ & 12 & 9.2 & 9.2 & 46.6 \\
$\begin{array}{l}\text { Disagree } \\
\text { strongly }\end{array}$ & 50 & 5.8 & 5.8 & 52.4 \\
disagree & 48 & 24.3 & 24.3 & 76.7 \\
Total & 206 & 23.3 & 23.3 & 100 \\
\hline
\end{tabular}

From table 4.5 above, $17.5 \%$ of respondents strongly agreed, $19.9 \%$ agreed, $9.2 \%$ somehow agreed, $5.8 \%$ somehow disagreed, $24.3 \%$ disagreed and $23.3 \%$ strongly disagreed that orientation on data collection tool of School based hand washing project in Kwale County is conducted regularly. The total percentage of the respondents who agreed is $46.6 \%$ while those respondents who disagreed is $53.4 \%$ which brings a cumulative percentage of $100.0 \%$. The data reveals that more than a half of the respondents disagree that orientation on data collection tool is conducted which determines monitoring and evaluation of the project.

\subsection{Project Organization Culture}

Project organization culture is one of the factors which determine if a project is to be monitored and evaluated or not. The tables below shows the frequencies and percentages of the respondents as per the statement on project organization culture and monitoring and evaluation of School based hand washing project in Kwale County.

You understand the project organization culture of School based hand washing project in Kwale County. The response was as shown in table 4.6.

Table 4.6. Project organization culture.

\begin{tabular}{lllll}
\hline Reaction & Frequency & Percent & $\begin{array}{l}\text { Valid } \\
\text { Percent }\end{array}$ & $\begin{array}{l}\text { Cumulative } \\
\text { Percent }\end{array}$ \\
\hline $\begin{array}{l}\text { Strong } \\
\text { Agree }\end{array}$ & 21 & 10.2 & 10.2 & 10.2 \\
$\begin{array}{l}\text { Agree } \\
\begin{array}{l}\text { Somehow } \\
\text { agree }\end{array}\end{array}$ & 51 & 24.8 & 24.8 & 35 \\
$\begin{array}{l}\text { somehow } \\
\text { disagree }\end{array}$ & 27 & 17.5 & 17.5 & 52.4 \\
$\begin{array}{l}\text { Disagree } \\
\text { strongly }\end{array}$ & 30 & 13.1 & 13.1 & 65.5 \\
$\begin{array}{l}\text { disagree } \\
\text { Total }\end{array}$ & 41 & 14.6 & 14.6 & 80.1 \\
\hline
\end{tabular}

From table 4.6 above, $10.2 \%$ of respondents strongly agreed, $24.8 \%$ agreed, $17.5 \%$ somehow agreed, $13.1 \%$ somehow disagreed, $14.6 \%$ disagreed and $19.9 \%$ strongly disagreed that they understand project organization culture of School based hand washing project in Kwale County is conducted regularly. The total percentage of the respondents who agreed is $52.4 \% \%$ while those respondents who disagreed is $47.6 \%$ which brings a cumulative percentage of $100.0 \%$. The data reveals that more than a half of the respondents agree that they understand project organization culture of School based hand washing project which play a role in monitoring and evaluation of the project.

School based hand washing project in Kwale County is organized in such a way that everyone is involved in the project activities at different level. The responses were as in table 4.7 
Table 4.7. School based hand washing project activities in Kwale County is participatory.

\begin{tabular}{lllll}
\hline Reaction & Frequency & Percent & $\begin{array}{l}\text { Valid } \\
\text { Percent }\end{array}$ & $\begin{array}{l}\text { Cumulative } \\
\text { Percent }\end{array}$ \\
\hline $\begin{array}{l}\text { Strong } \\
\text { Agree }\end{array}$ & 27 & 13.1 & 13.1 & 13.1 \\
$\begin{array}{l}\text { Agree } \\
\begin{array}{l}\text { Somehow } \\
\text { agree }\end{array}\end{array}$ & 42 & 20.4 & 20.4 & 33.5 \\
$\begin{array}{l}\text { somehow } \\
\text { disagree }\end{array}$ & 35 & 24.3 & 24.3 & 57.8 \\
$\begin{array}{l}\text { Disagree } \\
\text { strongly }\end{array}$ & 26 & 17 & 17 & 74.8 \\
disagree & 26 & 12.6 & 12.6 & 87.4 \\
Total & 206 & 12.6 & 12.6 & 100 \\
\hline
\end{tabular}

From table 4.7 above, statistically $13.1 \%$ of respondents strongly agreed, 20.4\% agreed, 24.3\% somehow agreed, $17.0 \%$ somehow disagreed, $12.6 \%$ disagreed and $12.6 \%$ strongly disagreed that they School based hand washing project in Kwale County activities is participatory. The total percentage of the respondents who agreed is $57.8 \%$ while those respondents who disagreed is $42.2 \%$ which brings a cumulative percentage of $100.0 \%$. The data stipulates that more than a half of the respondents agree that School based hand washing project activities is participatory and it plays a major role in monitoring and evaluation of the project.

Kwale County School based hand washing project has M\&E plan. The response was as shown in table 4.8

Table 4.8. Kwale County School based M\&E Plan.

\begin{tabular}{lllll}
\hline Reaction & Frequency & Percent & $\begin{array}{l}\text { Valid } \\
\text { Percent }\end{array}$ & $\begin{array}{l}\text { Cumulative } \\
\text { Percent }\end{array}$ \\
\hline $\begin{array}{l}\text { Strong } \\
\text { Agree }\end{array}$ & 20 & 9.7 & 9.7 & 9.7 \\
$\begin{array}{l}\text { Agree } \\
\text { Somehow }\end{array}$ & 47 & 22.8 & 22.8 & 32.5 \\
$\begin{array}{l}\text { agree } \\
\text { somehow }\end{array}$ & 48 & 23.3 & 23.3 & 55.8 \\
$\begin{array}{l}\text { disagree } \\
\begin{array}{l}\text { Disagree } \\
\text { strongly }\end{array}\end{array}$ & 16 & 7.8 & 7.8 & 63.6 \\
$\begin{array}{l}\text { disagree } \\
\text { Total }\end{array}$ & 23 & 25.2 & 25.2 & 88.8 \\
\hline
\end{tabular}

From table 4.8 above, statistically $9.7 \%$ of respondents strongly agreed, 22.8\% agreed, 24.3\% somehow agreed, $7.8 \%$ somehow disagreed, $25.2 \%$ disagreed and $11.2 \%$ strongly disagreed that they School based hand washing project in Kwale County has a M\&E plan. The total percentage of the respondents who agreed is $55.8 \%$ while those respondents who disagreed is $42.2 \%$ which brings a cumulative percentage of $100.0 \%$. More than a half of the respondents agree that School based hand washing project activities has a Monitoring and evaluation plan which has an influence in monitoring and evaluation of the project.

You are aware of your roles and responsibilities in Kwale County School based hand washing project. The findings were as presented in table 9
Table 4.9. Roles and responsibilities.

\begin{tabular}{lllll}
\hline Reaction & Frequency & Percent & $\begin{array}{l}\text { Valid } \\
\text { Percent }\end{array}$ & $\begin{array}{l}\text { Cumulative } \\
\text { Percent }\end{array}$ \\
\hline $\begin{array}{l}\text { Strong } \\
\text { Agree }\end{array}$ & 46 & 22.3 & 22.3 & 22.3 \\
$\begin{array}{l}\text { Agree } \\
\text { Somehow }\end{array}$ & 40 & 19.4 & 19.4 & 41.7 \\
$\begin{array}{l}\text { agree } \\
\text { somehow }\end{array}$ & 37 & 18 & 18 & 59.7 \\
$\begin{array}{l}\text { disagree } \\
\text { Disagree }\end{array}$ & 39 & 8.7 & 8.7 & 68.4 \\
$\begin{array}{l}\text { strongly } \\
\text { disagree }\end{array}$ & 26 & 18.9 & 18.9 & 87.4 \\
Total & 206 & 12.6 & 12.6 & 100 \\
\hline
\end{tabular}

From table 4.9 above, statistically $22.3 \%$ of respondents strongly agreed, $19.4 \%$ agreed, $18.0 \%$ somehow agreed, $8.7 \%$ somehow disagreed, $18.9 \%$ disagreed and $12.6 \%$ strongly disagreed that they understand their roles and responsibilities in School based hand washing project in Kwale County. The total percentage of the respondents who agreed is $59.7 \%$ while those respondents who disagreed is $40.3 \%$ which brings a cumulative percentage of $100.0 \%$. More than a half of the respondents agree that they understand their roles and responsibilities in School based hand washing project activities which determines monitoring and evaluation of project.

I am aware of monitoring and evaluation component in the management of Kwale School based hand washing project

Table 4.10. Components of monitoring and evaluation.

\begin{tabular}{lllll}
\hline Reaction & Frequency & Percent & $\begin{array}{l}\text { Valid } \\
\text { Percent }\end{array}$ & $\begin{array}{l}\text { Cumulative } \\
\text { Percent }\end{array}$ \\
\hline $\begin{array}{l}\text { Strong } \\
\text { Agree }\end{array}$ & 38 & 18.4 & 18.4 & 18.4 \\
$\begin{array}{l}\text { Agree } \\
\text { Somehow }\end{array}$ & 34 & 16.5 & 16.5 & 35 \\
$\begin{array}{l}\text { agree } \\
\text { somehow } \\
\text { disagree }\end{array}$ & 14 & 20.9 & 20.9 & 55.8 \\
$\begin{array}{l}\text { Disagree } \\
\text { strongly } \\
\text { disagree }\end{array}$ & 32 & 6.8 & 6.8 & 62.6 \\
\begin{tabular}{l} 
Total \\
\hline
\end{tabular} & 206 & 15.5 & 15.5 & 78.2 \\
\hline
\end{tabular}

From table 4.10 above, statistically $18.4 \%$ of respondents strongly agreed, $16.5 \%$ agreed, $20.9 \%$ somehow agreed, $6.8 \%$ somehow disagreed, $15.5 \%$ disagreed and $21.8 \%$ strongly disagreed that they understand components of monitoring and evaluation in School based hand washing project in Kwale County. The total percentage of the respondents who agreed is $55.8 \%$ while those respondents who disagreed is $44.2 \%$ which brings a cumulative percentage of $100.0 \%$. More than a half of the respondents agree that they understand components of M\&E of School based hand washing project which determines monitoring and evaluation of project.

Project organization culture of Kwale County school based hand washing is helpful in M\&E of the project progress. 
Table 4.11. Project organization culture and project progress.

\begin{tabular}{lllll}
\hline Reaction & Frequency & Percent & $\begin{array}{l}\text { Valid } \\
\text { Percent }\end{array}$ & $\begin{array}{l}\text { Cumulative } \\
\text { Percent }\end{array}$ \\
\hline $\begin{array}{l}\text { Strong } \\
\text { Agree }\end{array}$ & 54 & 26.2 & 26.2 & 26.2 \\
$\begin{array}{l}\text { Agree } \\
\text { Somehow }\end{array}$ & 42 & 20.4 & 20.4 & 46.6 \\
$\begin{array}{l}\text { agree } \\
\text { somehow }\end{array}$ & 37 & 18 & 18 & 64.6 \\
$\begin{array}{l}\text { disagree } \\
\begin{array}{l}\text { Disagree } \\
\text { strongly }\end{array}\end{array}$ & 27 & 6.3 & 6.3 & 70.9 \\
$\begin{array}{l}\text { disagree } \\
\text { Total }\end{array}$ & 33 & 13.1 & 13.1 & 84 \\
\hline
\end{tabular}

From table 4.11 above, statistically $26.2 \%$ of respondents strongly agreed, $20.4 \%$ agreed, $18.0 \%$ somehow agreed, $6.3 \%$ somehow disagreed, $13.1 \%$ disagreed and $16.0 \%$ strongly disagreed that they understand components of monitoring and evaluation in School based hand washing project in Kwale County. The total percentage of the respondents who agreed is $64.6 \%$ while those respondents who disagreed is $35.4 \%$ which brings a cumulative percentage of $100.0 \%$. More than a half of the respondents agree that they understand components of M\&E of School based hand washing project which plays a major role in determining monitoring and evaluation of project.

\subsection{Stakeholders Participation}

Stakeholders' participation in project is one of the factors which influences monitoring and evaluation. The tables below shows the frequencies and percentages of the respondents as per the statement on project stakeholders and monitoring and evaluation of School based hand washing project in Kwale County.

I am aware of all the stakeholders involved in M\&E of Kwale County School based hand washing project.

Table 4.12. Stakeholders.

\begin{tabular}{lllll}
\hline Reaction & Frequency & Percent & $\begin{array}{l}\text { Valid } \\
\text { Percent }\end{array}$ & $\begin{array}{l}\text { Cumulative } \\
\text { Percent }\end{array}$ \\
\hline $\begin{array}{l}\text { Strong } \\
\text { Agree }\end{array}$ & 20 & 9.7 & 9.7 & 9.7 \\
$\begin{array}{l}\text { Agree } \\
\begin{array}{l}\text { Somehow } \\
\text { agree }\end{array}\end{array}$ & 32 & 15.5 & 15.5 & 25.2 \\
$\begin{array}{l}\text { somehow } \\
\text { disagree }\end{array}$ & 8 & 24.8 & 24.8 & 50 \\
$\begin{array}{l}\text { Disagree } \\
\text { strongly }\end{array}$ & 50 & 3.9 & 3.9 & 53.9 \\
$\begin{array}{l}\text { disagree } \\
\text { Total }\end{array}$ & 45 & 24.3 & 24.3 & 78.2 \\
\hline
\end{tabular}

From table 4.12 above, statistically $9.7 \%$ of respondents strongly agreed, $15.5 \%$ agreed, $24.8 \%$ somehow agreed, $3.9 \%$ somehow disagreed, $24.3 \%$ disagreed and $21.8 \%$ strongly disagreed that they are aware of stakeholders involved in monitoring and evaluation of School based hand washing project in Kwale County. The total percentage of the respondents who agreed is $50.0 \%$ while those respondents who disagreed is $50.0 \%$ which brings a cumulative percentage of $100.0 \%$. A half of the respondents agree that they are aware of School based hand washing project stakeholders' and their roles in monitoring and evaluation of the project.

I understand the roles and responsibilities of the stakeholders in M\&E of School based hand washing project

Table 4.13. Roles and responsibilities of stakeholders.

\begin{tabular}{lllll}
\hline Reaction & Frequency & Percent & $\begin{array}{l}\text { Valid } \\
\text { Percent }\end{array}$ & $\begin{array}{l}\text { Cumulative } \\
\text { Percent }\end{array}$ \\
\hline $\begin{array}{l}\text { Strong } \\
\begin{array}{l}\text { Agree } \\
\text { Agree }\end{array}\end{array}$ & 13 & 6.3 & 6.3 & 6.3 \\
$\begin{array}{l}\text { Somehow } \\
\text { agree }\end{array}$ & 53 & 17.5 & 17.5 & 23.8 \\
$\begin{array}{l}\text { somehow } \\
\text { disagree }\end{array}$ & 21 & 25.7 & 25.7 & 49.5 \\
$\begin{array}{l}\text { Disagree } \\
\text { strongly } \\
\text { disagree }\end{array}$ & 42 & 10.2 & 10.2 & 59.7 \\
Total & 41 & 20.4 & 20.4 & 80.1 \\
\hline
\end{tabular}

From table 4.13 above, statistically $6.3 \%$ of respondents strongly agreed, $17.5 \%$ agreed, $25.7 \%$ somehow agreed, $10.2 \%$ somehow disagreed, $20.4 \%$ disagreed and $19.9 \%$ strongly disagreed that they are aware of roles and responsibilities of stakeholders involved in monitoring and evaluation of School based hand washing project in Kwale County. The total percentage of the respondents who agreed is $49.5 \%$ while those respondents who disagreed is $50.5 \%$ which brings a cumulative percentage of $100.0 \%$. Less than a half of the respondents agree that they are aware of roles and responsibilities of School based hand washing project.

I am aware of the key stakeholders in M\&E of school based hand washing

Table 4.14. Key stakeholders.

\begin{tabular}{lllll}
\hline Reaction & Frequency & Percent & $\begin{array}{l}\text { Valid } \\
\text { Percent }\end{array}$ & $\begin{array}{l}\text { Cumulative } \\
\text { Percent }\end{array}$ \\
\hline $\begin{array}{l}\text { Strong } \\
\text { Agree }\end{array}$ & 17 & 8.3 & 8.3 & 8.3 \\
$\begin{array}{l}\text { Agree } \\
\begin{array}{l}\text { Somehow } \\
\text { agree }\end{array}\end{array}$ & 35 & 17 & 17 & 25.2 \\
$\begin{array}{l}\text { somehow } \\
\text { disagree }\end{array}$ & 19 & 19.9 & 19.9 & 45.1 \\
$\begin{array}{l}\text { Disagree } \\
\text { strongly } \\
\text { disagree }\end{array}$ & 61 & 9.2 & 9.2 & 54.4 \\
Total & 206 & 29.6 & 29.6 & 84 \\
\hline
\end{tabular}

From table 4.14 above, statistically $8.3 \%$ of respondents strongly agreed, $17.0 \%$ agreed, $19.9 \%$ somehow agreed, $9.2 \%$ somehow disagreed, $29.6 \%$ disagreed and 19.9\% strongly disagreed that they are aware of key stakeholders involved in monitoring and evaluation in School based hand washing project in Kwale County. The total percentage of the respondents who agreed is $45.1 \%$ while those respondents who disagreed is $54.9 \%$ which brings a cumulative percentage of $100.0 \%$. Less than a half of the respondents agreed that they are aware of key stakeholders in School based hand washing project in Kwale County. 
I understand that Kwale School based hand washing M\&E reports are shared with all the stakeholders.

Table 4.15. M\&E reports shared.

\begin{tabular}{lllll}
\hline Reaction & Frequency & Percent & $\begin{array}{l}\text { Valid } \\
\text { Percent }\end{array}$ & $\begin{array}{l}\text { Cumulative } \\
\text { Percent }\end{array}$ \\
\hline Strong & 13 & 6.3 & 6.3 & 6.3 \\
Agree & 27 & 13.1 & 13.1 & 19.4 \\
$\begin{array}{l}\text { Agree } \\
\text { Somehow }\end{array}$ & 48 & 23.3 & 23.3 & 42.7 \\
agree & & 12.6 & 12.6 & 55.3 \\
$\begin{array}{l}\text { somehow } \\
\text { disagree }\end{array}$ & 26 & 21.4 & 21.4 & 76.7 \\
$\begin{array}{l}\text { Disagree } \\
\text { strongly }\end{array}$ & 44 & 23.3 & 23.3 & 100 \\
disagree & 48 & 100 & 100 & \\
Total & 206 & & & \\
\hline
\end{tabular}

From table 4.15 above, statistically $6.3 \%$ of respondents strongly agreed, $13.1 \%$ agreed, $23.3 \%$ somehow agreed, $12.6 \%$ somehow disagreed, $21.4 \%$ disagreed and $23.3 \%$ strongly disagreed that School based hand washing project in Kwale County reports are shared with all stakeholders. The total percentage of the respondents who agreed is $42.7 \%$ while those respondents who disagreed is $57.3 \%$ which brings a cumulative percentage of $100.0 \%$. Less than a half of the respondents agree that the reports are shared with all the stakeholders.

I am aware of stakeholders' contribution on M\&E of School based hand washing project.

Table 4.16. Stakeholders contribution.

\begin{tabular}{lllll}
\hline Reaction & Frequency & Percent & $\begin{array}{l}\text { Valid } \\
\text { Percent }\end{array}$ & $\begin{array}{l}\text { Cumulative } \\
\text { Percent }\end{array}$ \\
\hline $\begin{array}{l}\text { Strong } \\
\text { Agree }\end{array}$ & 20 & 9.7 & 9.7 & 9.7 \\
$\begin{array}{l}\text { Agree } \\
\begin{array}{l}\text { Somehow } \\
\text { agree }\end{array}\end{array}$ & 26 & 12.6 & 12.6 & 22.3 \\
$\begin{array}{l}\text { somehow } \\
\text { disagree }\end{array}$ & 24 & 23.3 & 23.3 & 45.6 \\
$\begin{array}{l}\text { Disagree } \\
\text { strongly }\end{array}$ & 44 & 11.7 & 11.7 & 57.3 \\
disagree & 44 & 21.4 & 21.4 & 78.6 \\
Total & 206 & 21.4 & 21.4 & 100 \\
\hline
\end{tabular}

From table 4.16 above, statistically $9.7 \%$ of respondents strongly agreed, $12.6 \%$ agreed, $23.3 \%$ somehow agreed, $11.7 \%$ somehow disagreed, $21.4 \%$ disagreed and $21.4 \%$ strongly disagreed that they are aware of stakeholders contribution of School based hand washing project in Kwale County reports are shared with all stakeholders. The total percentage of the respondents who agreed is $44.6 \%$ while those respondents who disagreed is $55.4 \%$ which brings a cumulative percentage of $100.0 \%$. Less than a half of the respondents agree that they are aware of stakeholders' contribution in School based hand washing project in Kwale County.

\subsection{Project Advocacy}

Project advocacy is one of the factors which determines monitoring and evaluation. The tables below shows the frequencies and percentages of the respondents as per the statement on project advocacy and of School based hand washing project in Kwale County.

I am an advocate of school based hand washing project in Kwale County

Table 4.17. Advocate for hand washing.

\begin{tabular}{lllll}
\hline Reaction & Frequency & Percent & $\begin{array}{l}\text { Valid } \\
\text { Percent }\end{array}$ & $\begin{array}{l}\text { Cumulative } \\
\text { Percent }\end{array}$ \\
\hline $\begin{array}{l}\text { Strong } \\
\text { Agree }\end{array}$ & 26 & 12.6 & 12.6 & 12.6 \\
$\begin{array}{l}\text { Agree } \\
\begin{array}{l}\text { Somehow } \\
\text { agree }\end{array}\end{array}$ & 28 & 19.4 & 19.4 & 32 \\
$\begin{array}{l}\text { somehow } \\
\text { disagree }\end{array}$ & 22 & 13.6 & 13.6 & 45.6 \\
$\begin{array}{l}\text { Disagree } \\
\text { strongly } \\
\text { disagree }\end{array}$ & 41 & 10.7 & 10.7 & 56.3 \\
Total & 49 & 19.9 & 19.9 & 76.2 \\
\hline
\end{tabular}

From table 4.17 above, statistically $12.6 \%$ of respondents strongly agreed, $19.4 \%$ agreed, $13.6 \%$ somehow agreed, $10.7 \%$ somehow disagreed, $19.9 \%$ disagreed and $23.8 \%$ strongly disagreed that they are advocates of School based hand washing project in Kwale County. The total percentage of the respondents who agreed is $45.6 \%$ while those respondents who disagreed is $54.4 \%$ which brings a cumulative percentage of $100.0 \%$. Less than a half of the respondents agree that they are advocates for School based hand washing project in Kwale County.

I am aware of major advocacy strategy used to create awareness of School based hand washing project.

Table 4.18. Project advocacy strategy.

\begin{tabular}{lllll}
\hline Reaction & Frequency & Percent & $\begin{array}{l}\text { Valid } \\
\text { Percent }\end{array}$ & $\begin{array}{l}\text { Cumulative } \\
\text { Percent }\end{array}$ \\
\hline Strong Agree & 20 & 9.7 & 9.7 & 9.7 \\
Agree & 32 & 15.5 & 15.5 & 25.2 \\
Somehow agree & 41 & 19.9 & 19.9 & 45.1 \\
somehow & 30 & 14.6 & 14.6 & 59.7 \\
disagree & 27 & 13.1 & 13.1 & 72.8 \\
Disagree & 27.2 & 27.2 & 100 \\
strongly disagree & 56 & 100 & 100 & \\
Total & 206 & & & \\
\hline
\end{tabular}

From table 4.18 above, statistically $9.7 \%$ of respondents strongly agreed, $15.5 \%$ agreed, $19.9 \%$ somehow agreed, $14.6 \%$ somehow disagreed, $13.1 \%$ disagreed and $27.2 \%$ strongly disagreed that they are aware of advocacy strategies of School based hand washing project in Kwale County reports are shared with all stakeholders. The total percentage of the respondents who agreed is $45.1 \%$ while those respondents who disagreed is $55.4 \%$ which brings a cumulative percentage of $100.0 \%$. Less 
than a half of the respondents agree that they are aware of advocacy strategies used in School based hand washing project in Kwale County.

I am aware of the support available to the advocates of School based hand washing project in Kwale County

Table 4.19. Support available for advocates.

\begin{tabular}{lllll}
\hline Reaction & Frequency & Percent & $\begin{array}{l}\text { Valid } \\
\text { Percent }\end{array}$ & $\begin{array}{l}\text { Cumulative } \\
\text { Percent }\end{array}$ \\
\hline $\begin{array}{l}\text { Strong } \\
\text { Agree }\end{array}$ & 19 & 9.2 & 9.2 & 9.2 \\
$\begin{array}{l}\text { Agree } \\
\text { Somehow }\end{array}$ & 27 & 13.1 & 13.1 & 22.3 \\
$\begin{array}{l}\text { agree } \\
\text { somehow } \\
\text { disagree }\end{array}$ & 19 & 22.3 & 22.3 & 44.7 \\
$\begin{array}{l}\text { Disagree } \\
\text { strongly }\end{array}$ & 39 & 9.2 & 9.2 & 53.9 \\
$\begin{array}{l}\text { disagree } \\
\text { Total }\end{array}$ & 56 & 18.9 & 18.9 & 72.8 \\
\hline
\end{tabular}

From table 4.19 above, statistically $9.2 \%$ of respondents strongly agreed, $13.1 \%$ agreed, $22.3 \%$ somehow agreed, $9.2 \%$ somehow disagreed, $18.9 \%$ disagreed and $27.2 \%$ strongly disagreed that they are aware of support for advocates of School based hand washing project in Kwale County. The total percentage of the respondents who agreed is $44.7 \%$ while those respondents who disagreed is $55.3 \%$ which brings a cumulative percentage of $100.0 \%$.

I am aware of resistance to advocacy amongst stakeholders in implementing School based hand washing project

Table 4.20. Resistance to advocacy amongst stakeholders.

\begin{tabular}{lllll}
\hline Reaction & Frequency & Percent & $\begin{array}{l}\text { Valid } \\
\text { Percent }\end{array}$ & $\begin{array}{l}\text { Cumulative } \\
\text { Percent }\end{array}$ \\
\hline $\begin{array}{l}\text { Strong } \\
\text { Agree }\end{array}$ & 12 & 5.8 & 5.8 & 5.8 \\
$\begin{array}{l}\text { Agree } \\
\begin{array}{l}\text { Somehow } \\
\text { agree }\end{array}\end{array}$ & 28 & 13.6 & 13.6 & 19.4 \\
$\begin{array}{l}\text { somehow } \\
\text { disagree }\end{array}$ & 23 & 22.3 & 22.3 & 41.7 \\
$\begin{array}{l}\text { Disagree } \\
\text { strongly }\end{array}$ & 31 & 11.2 & 11.2 & 52.9 \\
$\begin{array}{l}\text { disagree } \\
\text { Total }\end{array}$ & 66 & 15 & 15 & 68 \\
\hline
\end{tabular}

From table 4.20 above, statistically $5.8 \%$ of respondents strongly agreed, $13.6 \%$ agreed, $22.3 \%$ somehow agreed, $11.2 \%$ somehow disagreed, $15 \%$ disagreed and $32 \%$ strongly disagreed that they are aware of resistance to advocacy of School based hand washing project in Kwale County. The total percentage of the respondents who agreed is $41.7 \%$ while those respondents who disagreed is $58.3 \%$ which brings a cumulative percentage of $100.0 \%$.

I am aware the stakeholders work effectively in order to advocate for mutually desirable policy changes for school based hand washing project
Table 4.21. Effectiveness of stakeholders.

\begin{tabular}{lllll}
\hline & Frequency & Percent & $\begin{array}{l}\text { Valid } \\
\text { Percent }\end{array}$ & $\begin{array}{l}\text { Cumulative } \\
\text { Percent }\end{array}$ \\
\hline 1 & 17 & 8.3 & 8.3 & 8.3 \\
2 & 30 & 14.6 & 14.6 & 22.8 \\
3 & 30 & 14.6 & 14.6 & 37.4 \\
4 & 21 & 10.2 & 10.2 & 47.6 \\
5 & 50 & 24.3 & 24.3 & 71.8 \\
6 & 58 & 28.2 & 28.2 & 100 \\
Total & 206 & 100 & 100 & \\
\hline
\end{tabular}

From table 4.21 above, statistically $8.3 \%$ of respondents strongly agreed, $14.6 \%$ agreed, $14.6 \%$ somehow agreed, $10.2 \%$ somehow disagreed, $24.3 \%$ disagreed and $28.2 \%$ strongly disagreed that stakeholders work effectively in order to advocate for mutually desirable policy changes for School based hand washing project in Kwale County. The total percentage of the respondents who agreed is $37.4 \%$ while those respondents who disagreed is $62.6 \%$ which brings a cumulative percentage of $100.0 \%$. Less than a half of the respondents agreed with the statement.

\section{Conclusions and Recommendations}

Human resource plays a vital role in monitoring and evaluation of public health programs and the project team should be composed of specialized staffs that are properly trained to conduct monitoring and evaluation. Properly trained staffs in monitoring and evaluation are very useful to programs as they understand the importance of monitoring and evaluation and cooperate to avail data for monitoring purposes. For monitoring and evaluation systems to be functional properly, advocacy strategies need to be developed and supported within the organization. In addition, a culture to support monitoring and evaluation should be developed within the organization.

The recommendations from the study include the following; There is need to involve all the stakeholders in School based hand washing project and this will assist in strengthening monitoring and evaluation unit. Those who are involved in monitoring and evaluation of the project should be properly trained and orientation on the same conducted regularly for them to support the system. There is need to improve on advocacy strategies on School based hand washing project in Kwale County. Based on the study, there was slight association between project advocacy and monitoring and evaluation. For the success of the project, all stakeholders should be involved when conducting monitoring and evaluation. Lastly, M\&E plan for the School based hand washing project should be in place as this will improve efficiency and effectiveness of public health programs. There is need to explore and research on the following; Advocacy, Stakeholders' participation and the role of County Government in monitoring and evaluation of public health program. 


\section{References}

[1] Adams, J., Bartram, J., Chartier., Y., \& Sims, J. (2009).Water, sanitation and hygiene standards for schools in low-cost settings. Geneva, WHO.

[2] Adkins, B., \& Caldwell, D. (2004). "Firm or subgroup culture: Where does fitting in matter most?". Journal of Organizational Behaviour, 25(8) pp. 969-978.

[3] Aitchison, J. (1998). Access to books and journal articles by post-graduate students on a course-work Masters' programme in Information Studies at the University of Natal, 146 Pietermaritzburg. MIS Thesis. Department of Information Studies, University of Natal.

[4] Alkin, M. C. (2004). Evaluation roots. Thousand Oaks: Sage. (Ed.) $(2004 \mathrm{a}$

[5] Amanda, J. T. (2010). The Lambeth cholera outbreak of 1848-1849: the setting, causes, course and aftermath of an epidemic in London. McFarland. pp. 55-6. ISBN 978-0-7864-3989-8. Retrieved 5 April 2012.

[6] Alvesson, M. (2002). Understanding Organizational Culture. Sage Publications, London.

[7] Aubel, J. (1999). "Participatory Program Evaluation Manual Involving Program Stakeholders in the Evaluation Process", Catholic Relief Services, Child Survival and Technical Support Project, Second Edition, December 1999.

[8] Bamberger, M. (2009) Institutionalizing Impact Evaluation within the Framework of a Monitoring and Evaluation System. Washington, DC: IEG.

[9] Baron-Cohen, S., \& Hammer, J. (1997). Parents of children with Asperger Syndrome: what is the cognitive phenotype? Journal of Cognitive Neuroscience, 9, 548-554.

[10] Bate, P. (1995). Strategies for Cultural Change. Butterworth-Heinemann, Oxford.

[11] Bickman, L. (1987). The functions of program theory. New Directions for Program Evaluation, 33, 5-18.

[12] Bless, C., \& Higson-Smith, C. (2000). Fundamentals of social research methods (3rd ed.).An African perspective. Cape Town: Juta.

[13] Bowen, G. L. (2007). Social organization and schools: A general systems theory perspective. In P. Allen-Meares, Social work services in schools (5th ed., pp. 60-80). Boston: Pearson Education, Inc.

[14] Brickman, L., \& Rog., J. D, (1998).Handbook of Applied Social Research Methods. Thousand Oaks, CA: Sage Publications.

[15] Bundy, D.A., \& Guyatt., H.L. (1995). The health of school age children: report of a workshop. Parasitology Today, 13:438-443.

[16] Burman, R. and Evans, A.J. (2008). "Target Zero: A Culture of safety", Defence Aviation Safety Centre Journal, pp. 22-27.

[17] Chen, H. T. (1990). Theory-driven evaluations. Thousand Oaks, CA: Sage

[18] Chen, H. T., \& Rossi, P. H. (1983). Evaluating with sense: The theory-driven approach. Evaluation Review, 7, 283-302.Thousand Oaks, Calif: Sage
[19] Chitere, O. P., \& Ireri, O.N. (2004). District Focus for Rural Development in Kenya: It's Limitations as a Decentralization and participatory planning strategy and prospects for the future. Nairobi: Institute for Policy Analysis and Research.

[20] Collings, D. G., \& Wood, G. (2009). Human resource management: A critical approach. In D. G. Collings \& G. Wood (Eds.), Human resource management: A critical approach (pp. 1-16). London: Routledge.

[21] Cooper, D.R., \& Schindler, P.S. (2003). Business Research Methods. (8thed.). Boston: McGraw-Hill Irwin.

[22] Crawford, P., \& Bryce P. (2003): Project Monitoring and Evaluation: A method of enhancing the efficiency and effectiveness of aid project implementation. International Journal of Project Management, 21(5): 363 - 373

[23] Curtis, V., \& Cairncross, S. (2003). Effect of washing hands with soap on diarrhoea risk in the community: a systematic review, The Lancet Infectious Diseases, Vol. 3, May 2003, pp 275-281.

[24] Davidson, J. (2000). 10 Minute Guide to Project Management. Indianapolis: Alpha Books. (ISBN 0-02-863966-9)

[25] Davis, S.M. (1984). Managing Corporate Culture. Ballinger, Cambridge, MA.

[26] Donaldson, S., \& Lipsey, M. (2003). Roles for Theory in Contemporary Evaluation Practice: Developing Practical Knowledge, Evaluating Social Programs and Problems. Mahwah, NT: Erlbaum

[27] Drake LJ, Bundy DA. (2001). Multiple helmenthes infections in children: impact and control, Parasitology 122:S73-81.

[28] Dyal, W. (1995).Ten organizational practices of public health: a historical perspective. Am J Prev Med 1995; 11(6) Suppl 2:6-8. WW.

[29] Eskerod, P., Skriver, H. J. (2007). Organizational Culture Restraining In-House Knowledge Transfer Between Projects Managers - A Case Study. Project Management Journal. 38 (1), pp. 110-122.

[30] Fewtrell L et al. (2005). Water, sanitation, and hygiene interventions to reduce diarrhoea in less developed countries: a systematic review and meta-analysis, The Lancet Infectious Diseases, 2005, 5(1):42-52 doi: 10.1016/S1473-3099(04)01253-8.

[31] Freeman, M., L., \& Greene, et al. (2011). "Assessing the impact of a school based water treatment, hygiene, and sanitation program on pupil absence in Nyanza Province, Kenya: A cluster randomized trial." Tropical Medicine \& International Health doi: 10.1111/j.13653156.2011.02927.x. [Epub ahead of print].

[32] Funnel, S. (1997). Program logic: An adaptable tool for designing and evaluating programs. Evaluation News \& Comment, 5-17.

[33] Gargani, J. (2003). The history of theory-based evaluation: 1909 to 2003. Paper presented at the American Evaluation Association annual conference, Reno, NV.

[34] Gillham, B. (2008). Developing a questionnaire (2nd ed.). London, UK: Continuum International Publishing Group Ltd.

[35] Glass, G.V., \& Hopkins, K.D. (1984).Statistical methods in education and psychology. Englewood Cliffs, NJ: Prentice Hall. 
[36] Gosling, L., \& Cohen, D. (2007).Advocacy Matters: Helping children change their world. An International Save the Children Alliance guide to advocacy, Save the children UK.

[37] Gray, D. E. (2009). Doing research in the real world (2nd ed.). London, England: Sage.

[38] Guilford, J.P. \& Frucher, B .(1973). Fundamental Statistics in Psychology and Education, New York: MC Graw-Hill does cite Slovin (1960).

[39] Hellawell, J.M. (1991). Development of rationale for monitoring. Pg. 1-14 in Goldsmith, B. (ed.) Monitoring for Conservation and Ecology. Chapman and Hall, London.

[40] International Journal on Environmental Health. (2007).Monitoring progress of the role of integration of environmental health education with water and sanitation services in changing community behaviours. Int $\mathrm{J}$ Environ Health Res. 2007; 17:61-74. [PubMed].

[41] Johnason, P. (2009). HRM in changing organizational contexts. In D. G. Collings \& G. Wood (Eds.), Human resource management: A critical approach (pp. 19-37). London: Routledge.

[42] Jones, M. (2007) 'Integrating Stakeholder Theory and Strategic Management'. Paper presented at the IABS 2007 conference, Florence, May.

[43] Kothari, C. R. (2004). Research methodology. New Age International. New Delhi. India.Kothari, C.R. (2004). Research Methodology, Methods and Techniques. (Second Revised Edition), New Delhi: New Age International Publishers.

[44] Kram, K. E. (1985). Mentoring at work. Glenview, IL:Scott Forseman.

[45] Kvale, S. (1996).Interviews. Thousand Oaks: Sage Publication.

[46] Lavinghouze, R., Price, A.W., \& Smith, K.A.(2007). The Program Success Story: A Valuable Tool for Program Evaluation. Health Promotion Practice, 2007; 8(4): 323-331.

[47] Lewis, J. P. (1995). Fundamentals of project management. New York: Amacom.

[48] Leedy, P.D.(1989).Practical Research: Planning and Design.London:Collier,Macmillan

[49] Lundy, O., \& Cowling, A. (1996) Strategic human resource management. London: Routledge.

[50] Lusthaus, C. (1995). Institutional Assessment: A Framework for Strengthening Organizational Capacity for IDRC's Research Partners. Ottawa: IDRC.

[51] Martins, E.C., \& Terblanche, F. (2003). Building organizational culture that stimulates creativity and innovation.. European Journal of Innovation Management, Vol. 6, No. 1, pp. 64-74

[52] Marshall, P. L. (2002). Cultural Diversity in Our Schools. Belmont: Wadsworth.

[53] Maull, R.., Brown, P., \& Cliffe, R. (2001). Organisational culture and quality improvement. International Journal of Operations \& Production Management, Vol. 21, No. 3, pp. 302-326.

[54] May,. K. M. (1991).Interview techniques in qualitative research: concerns and challenges. In Morse JM (ed) Qualitative nursing research.pp 187-201.Newbury Park: Sage Publications.
[55] Mugenda \& Mugenda. (1999). Research Methods: Qualitative and Quantitative Approaches. Nairobi: Act Press

[56] N.et al. (2009). .Improving Impact Evaluation Coordination and Use. A Scoping study commissioned by the DFID Evaluation Department on behalf of NONIE (www.odi.org.uk/resources/download/3177.pdf). Retrieved June 15, 2011.

[57] Njenga SM, Mwandawiro CS, Muniu E, Mwanje MT, Haji FM, Bockarie MJ: Adult population as potential reservoir of NTD infections in rural villages of Kwale District, Coastal Kenya: implications for preventive chemotherapy interventions policy. Parasit Vectors 2011, 4:175. doi: $110.1186 / 1756-3305-1184-1175$

[58] Novick, L. F., Morrow, C. B., \& Mays, G. P. (2007). Public health administration: Principles for population-based management. Sudbury, Mass: Jones and Bartlett.

[59] Patton, Q. M. (1997). Utilization Focused Evaluation. The New Century Text (3rd Edition).Thousand Oaks: Sage Publications.

[60] Patton, M.Q. (2010). Developmental Evaluation: Applying Complexity Concepts to Enhance Innovation and Use. New York, NY: The Guilford Press, 2010.

[61] Pearce, J. \& Robinson, R. (2005). Strategic Management: Formulation, implementation, and control. (9th ed.). New York: McGraw-Hill.

[62] Perlino, C. (2006). The public health workforce: Left unchecked, will we be protected. APHA Issue Brief.

[63] Poister, H. (2007). Performance monitoring. Handbook of practical program evaluation (pp. 98-125). San Francisco: Jossey-Bass.

[64] Polit, D.F., Hungler, B.P. (1999) Nursing Research: Principles and Methods (6th edn).Philadelphia: J.B. Lippincott.

[65] Prochaska, J. O., \& DiClemente, C. C. (1999). The trans theoretical approach: Crossing traditional boundaries of change. Homewood, IL: Dow Jones/Irwin.

[66] Ravasi, D., Schultz, M. (2006). Responding to organizational identity threats: Exploring the role of organizational culture. Academy of Management Journal, 49(3), 433-458.

[67] Reidar, D. (2003).The logical frame work: an easy escape, a straightjacket, or a usefully planning tool. Journal of Development in Practice, 3(1): 57 - 70.

[68] Riley RD, Higgins JP, Deeks JJ. (2011) "Interpretation of random effects meta-analyses". British Medical Journal Feb 10;342:d549. doi:10.1136/bmj.d549

[69] Ross, P.H., Ellipse, M.W.,\& Freeman, H.E. (2004). Evaluation: A systematic approach (7th ed.). Thousand Oaks: Sage. ISBN 978-0-7619-0894-4.

[70] Rossi, Lipsey \& Freeman, (2004). "Chapter 6: Eras of the New Frontier and the Great Society, 1961-1969.

[71] Sanderson, C. J., \& Gruen, R. (2006). Analytical Models for Decision Making. Understanding Public Health. Open University Press. OCLC 182531015.

[72] Sarah del Tufo (2002). "WHAT is evaluation?" Evaluation Trust. The Evaluation Trust. Retrieved 13 May 2012. 
[73] Saunders, M. N. K. (2011). The management researcher as practitioner. Issues from the interface. In C. Cassell \& W. J. Lee (Eds.), Challenges and controversies in management research (pp. 243-256). London, England: Taylor and Francis.

[74] Sekaran, U. (2000). Research methods for business. New York: John Wiley \& Sons, Inc.

[75] Shadish, W. R. (1998). Need-based evaluation theory: What do you need to know to do good evaluation? Evaluation Practice, Thousand Oaks, California: Sage Publications.

[76] Shadish, W. R., Cook, T. D., \& Leviton, L. C. (1991). Foundations of program evaluation: Theories of practice. Thousand Oaks, California: Sage Publications.

[77] Shao, J. (1998). Convergence rates of the generalized information criterion. on-parametric Statistics, 9, 217-225.

[78] Shiller R. (2003), "From Efficient Markets Theory to Behavioral Finance", Journal of Economic Perspectives, vol. 17, n. 1.

[79] Shaughnessy, J.J., Zechmeister, E.B., Zechmeister, J.S. (2000). Research methods in psychology. Fifth edition. McGraw-Hill.

[80] Scriven, M. (1999). The nature of evaluation part ii: training. Practical Assessment, Research \& Evaluation, 6(12). Retrieved 2014fromhttp://PAREonline.net/getvn.asp?v=6\&n=12.

[81] Sofia, S., \& Emily, P.(2001). Advocacy Tools and Guidelines: Promoting Policy Change (Atlanta: CARE, 2001) .

[82] Sprechman, S., \& Pelton, E(2001). Advocacy Tools and Guidelines: Promoting Policy Change (Atlanta: CARE, 2001).

[83] Staff (2011). "Evaluation Purpose". designshop - lessons in effective teaching. Learning Technologies at Virginia Tech. Retrieved 13 May 2012.

[84] Stewardson, A.J., Allegranzi, B., Perneger, T.V., Attar, H., Pittet, D.(2013). Testing the WHO Hand Hygiene Self-Assessment Framework for usability and reliability. J Hosp Infect 2013; 83:30.

[85] Stewart ., D. W., Shamdasani., P. M.(1990).Focus groups. Theory and practice.London: Sage Publications.

[86] Stufflebeam., D. L. (Ed.) (2001). Evaluation models (New Directions for Evaluation, No.89). SanFrancisco, CA: Jossey-Bass.

[87] Thomas, G.( 2009 )How to do your research project. Sage Publications Inc.

[88] Turner, J. R..,\& Simister, S..J. (2000). Gower handbook of project management. (3th ed.) Hampshire: Gower.

[89] UNESCO. (2000).The Dakar Framework for Action: Education for All: Meeting our Collective Commitments. Paris UNESCO. Derived from the World Education Forum proceedings, Dakar, Senegal, April.

[90] UNDP. (1997) "Who are the Question-makers - A Participatory Evaluation Handbook", OESP, 1997.

[91] UNDP (1997). Results-Oriented Monitoring and Evaluation. New York. UNDP, OESP.
[92] UNICEF, (2008). State of the World's Children: child survival, UNICEF, New York, December 2007,pp .29-30.

[93] UNICEF, (2010). Water, Sanitation and Hygiene: Annual Report. New York: UNICEF, 2011

[94] Utah Department of Health.(2000). Utah Child Health Survey. Salt Lake City, Utah; 2001.

[95] Uttal, B. (1983). The corporate culture vultures. Fortune Magazine October 17.

[96] Van, D. A. (1996). The Assessment of Capacity Building. Windhoek, Namibia: UNICEF Namibia.

[97] Vanesa, W., \& Gala, D. (2011) Sound Expectations: From Impact Evaluations to Policy Change Center for the Implementation of Public Policies Promoting Equity and Growth (CIPPEC).

[98] Williams, A., Dobson, P. \& Walters, M. (1994). Changing Culture: New Organisational Approaches. (2nd ed). Cromwell Press, Wiltshire.

[99] WHO. (2005): Programme Report no. 17 - Seventeenth Programme Report of the UNICEF/UNDP/World Bank/WHO Special Programme for Research \& Training in Tropical Diseases. Geneva: World Health Organization; 2005.

[100] WHO, (2009) .WHO Disease and injury country estimates. Retrieved Nov 11, 2009

[101] WHO.(2009). "Public health principles and neurological disorders. In: Neurological Disorders: Public Health Challenges. Geneva; 2006 http://www.who.int/mental_health/neurology/neurodiso/en/ind ex.html

[102] WHO. (2012) .Accelerating work to overcome the global impact of neglected tropical diseases: a roadmap for implementation. In WHO/HTM/NTD/20121. Geneva: World Health Organization; 2012.

[103] Woodhill, J. 2006. "M\&E as Learning: Rethinking the Dominant Paradigm." In

[104]Monitoring and Evaluation of Soil Conservation and Watershed Development Projects, edited by J. de Graaff, J. Cameron, S. Sombatpanit, C. Pieri, and J. Woodhill.103-122. World Association of Soil and Water Conservation. Enfield, New Hampshire, USA: Science Publishers.

[105] World Bank (2006) .Disease control priorities in developing countries (2ndedition). New York: World Bank and Oxford University Press.

[106]Zall ,K. J.,\& Rist R.(2004) .Ten steps to a results-based monitoring and evaluation system. A handbook for development practitioners. Washington D.C.: The World Bank, 2004.

[107] Zechmeister, J. S., Zechmeister, E. B., \& Shaughnessy, J. J. (2001). Essentials of research methods in psychology, New York: Mc.

[108] Zhang, Xibao. (2009). Values, Expectations, Ad Hoc Rules, and Culture Emergence in International Cross Cultural Management Contexts. New York: Nova Science Publishers. 